\title{
Endothelin receptor subtypes in the microvillous trophoblastic membrane of early gestation and term human placentas
}

\author{
Françoise Mondon, Abdelmajid Anouar and Françoise Ferré \\ INSERM U. 361, Université René Descartes, Pavillon Baudelocque, 123 Bld de Port-Royal, 75014 Paris, France \\ (Correspondence should be addressed to F Mondon)
}

\begin{abstract}
The ${ }^{125}$ I-labeled endothelin-1 ([ $\left.\left.{ }^{125} \mathrm{I}\right] \mathrm{ET}-1\right)$ binding sites in microvillous membranes from early gestation and term human placentas were investigated. The $K_{\mathrm{d}} \mathrm{s}$ for $\left[{ }^{125} \mathrm{I}\right] \mathrm{ET}-1$ binding to early gestation $(68 \pm 15 \mathrm{pmol} / \mathrm{l})$ and term $(45 \pm 8 \mathrm{pmol} / \mathrm{l})$ microvilli $(n=4)$ were not significantly different. The density of binding sites decreased significantly, from $243 \pm 80 \mathrm{fmol} / \mathrm{mg}$ protein in early gestation microvilli to $54 \pm 10 \mathrm{fmol} / \mathrm{mg}$ protein in term microvilli. The endothelin (ET) receptor (ET-R) subtype profiles were determined by competition binding studies with unlabeled ET-1, ET-3, and selective agonists and antagonists for $\mathrm{ET}_{\mathrm{A}}-\mathrm{R}$ and $\mathrm{ET}_{\mathrm{B}}-\mathrm{R}$. In early gestation placental microvilli, we observed the presence of $72 \% \mathrm{ET}_{\mathrm{B}}-\mathrm{R}$, (mainly $\mathrm{ET}_{\mathrm{B} 2}-\mathrm{R}$ subtype), and $28 \% \mathrm{ET}_{\mathrm{A}}-\mathrm{R}$. Only $\mathrm{ET}_{\mathrm{B}}-\mathrm{R}$ (mainly the $\mathrm{ET}_{\mathrm{B} 2}-\mathrm{R}$ subtype) was present in term placental microvilli. We suggest that the $\mathrm{ET}_{\mathrm{B}}-\mathrm{R}$ on the placental microvillous membrane is involved in specific trophoblastic functions and may play a major role in ET clearance by modulating the amounts of ETs in the maternal intervillous blood space.
\end{abstract}

European Journal of Endocrinology 139 231-237

\section{Introduction}

Three endothelins (ETs), ET-1, ET-2 and ET-3, each 21 amino acid residues long and encoded by three separate genes, are found in the human genome (1). Although ET-1 was first described as a potent vasoactive peptide, subsequent studies have revealed that the ETs have many physiological and pathophysiological effects. ETs are pleiotropic factors controlling several aspects of cell function, such as ion fluxes, cell-to-cell communication, cell migration, neural transmission and the release of hormones and cytokines in neuroendocrine and immune systems. Like several other vasoactive substances, ETs also have growth factor properties (2). These diverse actions are partly attributed to the existence of many subtypes of ET receptors (ET-Rs) whose cellular distribution and functions are regulated. Sequence analysis of mammalian cDNA clones indicates that there are two distinct ET-R subtypes, $\mathrm{ET}_{\mathrm{A}}$-receptors $\left(\mathrm{ET}_{\mathrm{A}}-\mathrm{R}\right)$ and $\mathrm{ET}_{\mathrm{B}}$-receptors $\left(\mathrm{ET}_{\mathrm{B}}-\mathrm{R}\right)$, which belong to the superfamily of receptors with seven transmembrane domains that are coupled to heterotrimeric $\mathrm{G}$ proteins. $\mathrm{ET}_{\mathrm{A}}-\mathrm{R}$ is selective for ET-1 and ET-2, whereas $\mathrm{ET}_{\mathrm{B}}-\mathrm{R}$ binds to ET-1, ET-2 and ET-3 with equal affinity $(3,4)$. An additional subtype $\left(\mathrm{ET}_{\mathrm{c}}-\mathrm{R}\right)$, which is present in nonmammalian species and selectively binds ET-3, has been cloned (5). The functional significance of the ET-R subtypes remains a topic for considerable speculation. In vascular smooth muscle, $\mathrm{ET}_{\mathrm{A}}-\mathrm{R}$ and $\mathrm{ET}_{\mathrm{B}}-\mathrm{R}$ generally coexist. They mediate contraction and, as in other cell types, help control proliferation $(6,7) . \mathrm{ET}_{\mathrm{B}}-\mathrm{R}$ is probably the only receptor on the vascular endothelium, where it mediates relaxation of the neighboring muscle layer via the release of relaxing and antiproliferative factors such as nitric oxide and prostacyclin (8). $\mathrm{ET}_{\mathrm{B}}-\mathrm{R}$ is also the predominant subtype in epithelial and neural tissues.

In human placenta, ET-Rs were initially identified in crude membrane fractions $(9,10)$. They appear to be most abundant in first-trimester placentas, and their concentration gradually decreases towards term (11). The human placenta is a very complex endocrine organ and the ET system in each placental cell seems to develop and change during gestation (12). Specific high affinity ET-1 binding sites have been shown on fetoplacental vessels, trophoblasts and plasma membranes purified from the syncytiotrophoblast of term placentas (13-15). Transport through the microvillous membrane is the first step in placental transfer. This trophoblastic membrane, facing the maternal intervillous blood space where high concentrations of immunoreactive ETs (ir ETs) were found (16), is likely to play a major role in exchanges between maternal and fetal circulations.

The present study was designed to determine the ET-R subtypes of microvilli prepared from early gestation and term human placentas. For this purpose, the selective $\mathrm{ET}_{\mathrm{B}}-\mathrm{R}$ agonists sarafotoxin $6 \mathrm{c}$ (S6c) (17) and IRL 1620 (18), the selective $\mathrm{ET}_{\mathrm{B}}-\mathrm{R}$ antagonists $\mathrm{BQ} 788$ (19), IRL 2500 (20) and IRL 1038 (21), and the selective $\mathrm{ET}_{\mathrm{A}}-\mathrm{R}$ 
antagonist BQ 123 (22) were used as tools to define the ET-R profiles.

\section{Materials and methods}

\section{Placentas}

Term placentas were all obtained immediately after elective cesarean section from healthy mothers. The cesarean section was performed before labor under thiopental-sodium succinylcholine anesthesia in the 39 th week of pregnancy because of diagnosed cephalopelvic disproportion. No preoperative medication except atropine was given. Early gestation placentas were obtained from healthy mothers undergoing legal abortion by vacuum curetage between 8 and 10 weeks of amenorrhea.

\section{Placental microvilli preparation}

Placental microvilli were isolated by cold saline extraction and centrifugations using the modification of the method of Smith et al. (23) described by Alsat et al. (24). Briefly, the villous tissue was cut into small fragments and placed in $0.1 \mathrm{~mol} / \mathrm{CaCl}_{2}$ to remove blood. All subsequent procedures were performed at $4{ }^{\circ} \mathrm{C}$. The tissue was washed with isotonic Dulbecco's PBS pH 7.4, gently stirred for $30 \mathrm{~min}$ in the same buffer containing $10 \mu \mathrm{g} / \mathrm{ml}$ aprotinin, $1 \mu \mathrm{g} / \mathrm{ml}$ leupeptin and $25 \mu \mathrm{g} / \mathrm{ml}$ pefabloc, and the suspension filtered through a single thickness of cheesecloth. The filtrate was centrifuged at $800 \mathrm{~g}$ for $10 \mathrm{~min}$ to remove blood and cell debris and the resulting supernatant was centrifuged at $2500 \mathrm{~g}$ for $15 \mathrm{~min}$. The microvilli were sedimented from this second supernatant by centrifugation at $50000 \mathrm{~g}$ for $30 \mathrm{~min}$. The pellet was suspended in $50 \mathrm{mmol} / \mathrm{l}$ Tris$\mathrm{HCl}$ buffer $\mathrm{pH} 7.4$, frozen in liquid nitrogen and stored at $-80^{\circ} \mathrm{C}$.

The purity of the membrane preparations was checked by assaying marker enzyme activity and by electron microscopy using previously established procedures (25). Assay of the specific microvillous membrane enzyme, alkaline phosphatase, showed a 25-fold enrichment for early gestation microvillous preparations and a 17-fold enrichment for term microvilli. The purity of placental microvilli was also checked by the lack of adenylyl cyclase activity in both the early gestation and term membrane preparations and by ultrastructural studies (data not shown).

\section{Binding assay}

Binding studies were performed as previously described (15). Briefly, aliquots of membranes ( $10 \mu \mathrm{g}$ protein, in a final volume of $250 \mu \mathrm{l}$ ) were incubated for $60 \mathrm{~min}$ at $37^{\circ} \mathrm{C}$ with $2-300 \mathrm{pmol} / \mathrm{l}^{125}$ I-labeled ET-1 ([ $\left.\left[{ }^{125} \mathrm{I}\right] \mathrm{ET}-1\right)$ for saturation studies. Specific binding of $\left[{ }^{125} \mathrm{I}\right] \mathrm{ET}-1$ was defined as total binding minus binding not displaced by
$1 \mu \mathrm{mol} / \mathrm{l}$ unlabeled ET-1. At ligand concentrations near the dissociation constant $\left(K_{\mathrm{d}}\right)$, the non-specific binding was less than $10-15 \%$ of the total binding in the early gestation and in the term membrane preparations. Competition experiments were carried out using a fixed concentration of $\left[{ }^{125} \mathrm{I}\right] \mathrm{ET}-1(30 \mathrm{pmol} / \mathrm{l})$ and increasing concentrations of competing agents. All binding assays were performed at protein concentrations within the linear range.

The results are expressed, for each stage of pregnancy, as the means \pm s.E.M. of three to six separate experiments each on different placentas, performed singly for early gestation and in duplicate for term placentas. The $n$ values in this paper refer to the number of independent membrane preparations from distinct human placentas. Radioligand binding data were analyzed using the Inplot Computer program (GraphPad Software, San Diego, CA, USA). The inhibition constant $\left(K_{\mathrm{i}}\right)$ was calculated, for individual competition curves, by the equation of Cheng \& Prusoff (26), and $K_{\mathrm{d}}$ was determined by Scatchard analysis. Data were also subjected to non-linear least-square curve fitting using EBDA-LIGAND (Biosoft, Cambridge, UK) for simultaneous analysis of replicated competition curves. This enabled us to verify that the mean $K_{\mathrm{i}}$ values for each competition were the same as that averaged from the calculation made on individual curves, and that when applicable a two binding site model provided a significantly better fit, according to the $\mathrm{F}$ test, than a one binding site model (27). The protein concentration was determined by the method of Lowry using BSA as standard. Statistical differences were determined using ANOVA and Student's $t$-test for multiple comparisons. Significance was set at $P<0.05$.

\section{Chemicals}

$\left[{ }^{125} \mathrm{I}\right]$ ET-1 (specific activity $2000 \mathrm{Ci} / \mathrm{mmol}$ ) was purchased from Amersham International (Bucks, UK). ET-1, ET-3, S6c, BQ 123 [cyclo (D-Trp-D-Asp-Pro-D-ValLeu)], BQ 788 [N-cis-2, 6-dimethyl-piperidinocarbonyl-L- $\gamma$-methylleucyl-D-1 methoxycarbonyl-tryptophanyl-D-norleucine], IRL 2500 [N-(3,5-dimethyl benzoyl)-N-(methyl)-(D)-(4-phenylphenyl)-alanyl-L-tryptophan], IRL 1620 [succinyl-(Glu $\left.{ }^{9}, \mathrm{Ala}^{11,15}\right)$ endothe-

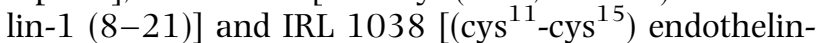
$1(11-21)]$ were all obtained from Neosystem (Strasbourg, France). Other drugs and chemicals used were of the highest quality available from Sigma Chemicals (St Louis, MO, USA).

\section{Results}

\section{Equilibrium studies}

$\left[{ }^{125}\right.$ I]ET-1 bound to microvillous membranes from early gestation and term placentas in a specific, saturable fashion and with high affinity (Fig. 1). Scatchard plots of 


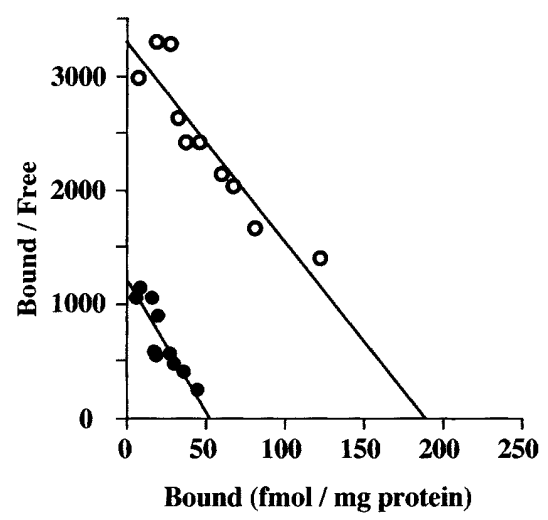

Figure 1 Scatchard analysis of [ $\left.{ }^{125}\right]$ ET-1 binding to term $(\bullet)$ and early gestation $(O)$ microvilli. Membranes were incubated with the indicated concentrations of $\left[{ }^{125} \mathrm{I}\right] \mathrm{ET}-1(2-300 \mathrm{pmol} / \mathrm{l})$ in the presence (non-specific binding) or absence (total binding) of $1 \mu \mathrm{mol} / /$ unlabeled ET-1. The data shown represent typical experiments performed in duplicate $(n=4)$.

the specific binding from saturation binding experiments were linear, indicating a single class of high affinity binding sites. The apparent $K_{\mathrm{d}}$ values for early gestation $(68 \pm 15 \mathrm{pmol} / \mathrm{l})$ and term microvillous membranes $(45 \pm 8 \mathrm{pmol} / \mathrm{l})(n=4)$ were not significantly different. The density of ET-R $\left(\mathrm{B}_{\max }\right)$ in term microvillous preparations was $54 \pm 10 \mathrm{fmol} / \mathrm{mg}$ protein. The values of $\mathrm{B}_{\max }$ for early gestation microvilli varied with the microvillous preparation. The mean value of $\mathrm{B}_{\max }$ for early gestation was $243 \pm 80 \mathrm{fmol} / \mathrm{mg}$ protein, which was five times greater than that for term microvilli.

\section{Competition binding experiments}

The profiles of ET-R subtypes in microvillous preparations were determined by measuring the binding of $\left[{ }^{125}\right.$ I]ET-1 in the presence of ET-R agonists and antagonists. In early gestation microvilli, ET-1, ET-3, S6c and IRL 1620 were all potent competitive inhibitors of $\left[{ }^{125} \mathrm{I}\right] \mathrm{ET}-1$ binding (Fig. 2A). ET-1 and ET-3 totally inhibited binding. A monophasic curve was obtained for ET- 1 with a $K_{\mathrm{i}}$ value of $35 \pm 5 \mathrm{pmol} / \mathrm{l}$. Two $K_{\mathrm{i}}$ values were determined for ET-3: one for high affinity sites $\left(K_{i}=28 \pm 3 \mathrm{pmol}\right)$ and one for low affinity sites $\left(K_{i}=4.6 \pm 1.4 \mathrm{nmol} / \mathrm{l}\right)$. The high affinity sites, which represented $72 \%$ of the total receptor population, had a $K_{\mathrm{i}}$ similar to that of ET-1 and were characteristic of the 'non-selective' or $\mathrm{ET}_{\mathrm{B}} \mathrm{R}$ subtype (4). The other sites, which represented $28 \%$ of total receptors, had a much lower affinity for ET-3 than for ET-1, typical of the $\mathrm{ET}_{\mathrm{A}}-\mathrm{R}$ subtype (3). These data were in agreement with the finding that the selective $\mathrm{ET}_{\mathrm{B}}-\mathrm{R}$ agonists $\mathrm{S} 6 \mathrm{c}$ and IRL 1620 displaced only $80 \%$ of $\left[{ }^{125} \mathrm{I}\right] \mathrm{ET}-1$, even up to $1 \mu \mathrm{mol} / \mathrm{l}$ (Fig. 2A). However, while the IRL 1620 displacement curve was monophasic (Hill coefficient close to unity) with a $K_{\mathrm{i}}$ value of $290 \pm 50 \mathrm{pmol} / \mathrm{l}$, S6c displaced the binding with two affinities: a high affinity
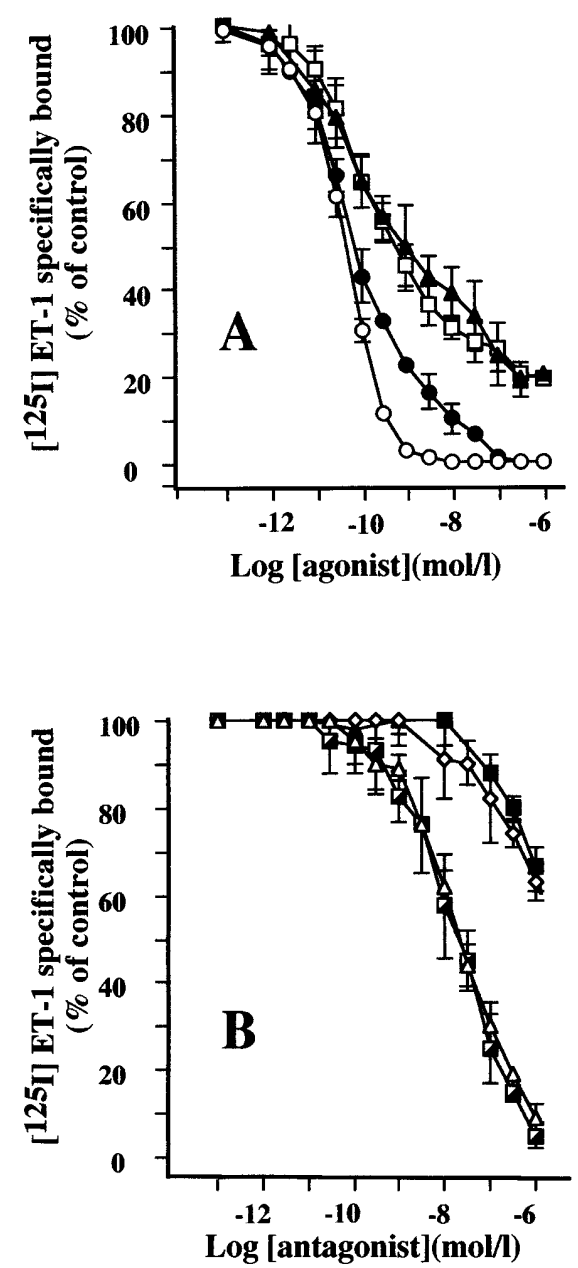

Figure 2 Displacement of [ $\left.{ }^{125} \mathrm{I}\right] \mathrm{ET}-1$ from early gestation microvilli

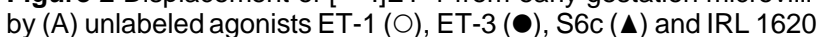
$(\square)$, and (B) by unlabeled antagonists BQ $788(\triangle)$, IRL 2500 (halffilled squares), IRL $1038(\boldsymbol{\square})$ and $B Q 123(\diamond)$. Membranes were incubated with $\left[{ }^{125} \mathrm{l}\right] \mathrm{ET}-1$ (30 pmol/l) and increasing concentrations of unlabeled ligands. Results are expressed as percentages of control (specific binding in the absence of unlabeled ligand). Nonspecific binding, determined in the presence of $1 \mu \mathrm{mol} / \mathrm{I} \mathrm{ET-1 \text {,was }}$ subtracted from the total binding. Each point is the mean \pm S.E.M. of three to six experiments from different placentas.

$K_{\mathrm{i}}$ value of $26 \pm 9 \mathrm{pmol} / \mathrm{l}$ ( $63 \%$ of total receptors) and a low affinity $K_{\mathrm{i}}$ value of $47 \pm 20 \mathrm{nmol} / \mathrm{l}$ (37\% of total receptors), suggesting the presence of different $\mathrm{ET}_{\mathrm{B}}-\mathrm{R}$ subtypes. Competitive experiments with antagonists confirmed these results (Fig. 2B): the selective $\mathrm{ET}_{\mathrm{B}}-\mathrm{R}$ antagonists BQ 788 and IRL 2500 almost totally displaced $\left[{ }^{125} \mathrm{I}\right] \mathrm{ET}-1$ with $K_{\mathrm{i}}$ values of $17 \pm 7$ and $22 \pm 6 \mathrm{nmol} / \mathrm{l}$ respectively, whereas the selective $\mathrm{ET}_{\mathrm{B}}-\mathrm{R}$ antagonist IRL 1038 only partially displaced it. The $\mathrm{ET}_{\mathrm{B}}-\mathrm{R}$ which is IRL 1038-insensitive has been shown to be of the $\mathrm{ET}_{\mathrm{B} 2}-\mathrm{R}$ subtype (28), indicating that in term microvilli, $\mathrm{ET}_{\mathrm{B}}-\mathrm{Rs}$ were mainly of the $\mathrm{ET}_{\mathrm{B} 2}-\mathrm{R}$ subtype. The selective $\mathrm{ET}_{\mathrm{A}}-\mathrm{R}$ antagonist $\mathrm{BQ} 123$ inhibited only $30 \%$ of $\left[{ }^{125}\right.$ I]ET-1 binding, even at concentrations of 

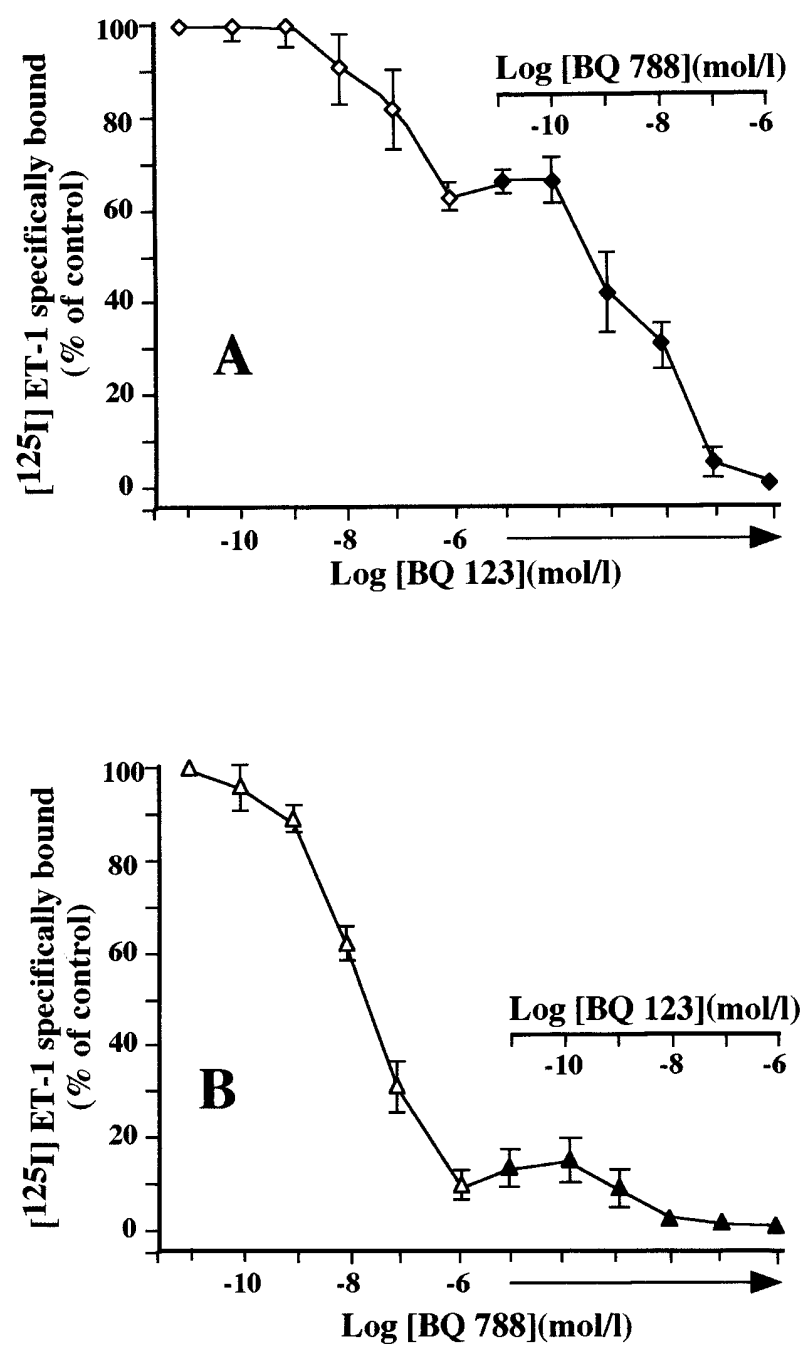

Figure $3(\mathrm{~A})$ Effects of $\mathrm{BQ} 123(0.1 \mathrm{nmol} / /$ to $1 \mu \mathrm{mol} / \mathrm{l})(\diamond)$ and $1 \mu \mathrm{mol} / / \mathrm{BQ} 123 \mathrm{plus} \mathrm{BQ} 788(10 \mathrm{pmol} / \mathrm{l}$ to $1 \mu \mathrm{mol} / \mathrm{l})(\diamond)$, and $(\mathrm{B})$ effects of BQ $788(10 \mathrm{pmol} / /$ to $1 \mu \mathrm{mol} / \mathrm{l}))(\Delta)$, and $1 \mu \mathrm{mol} / \mathrm{l} \mathrm{BQ} 788$ plus BQ $123(1 \mathrm{nmol} / \mathrm{l}$ to $1 \mu \mathrm{mol} / \mathrm{l})(\mathbf{\Lambda})$ on specific [ $\left.{ }^{125} \mathrm{l}\right] \mathrm{ET}-1$ binding to early gestation microvillous membranes. Each point is the mean \pm S.E.M. of three experiments from three different placentas.

$1 \mu \mathrm{mol} / \mathrm{l}$, indicating a minority of $\mathrm{ET}_{\mathrm{A}}-\mathrm{R}$. We confirmed these observations by investigating the effect of simultaneously blocking $\mathrm{ET}_{\mathrm{A}}-\mathrm{R}$ with $\mathrm{BQ} 123$ and $\mathrm{ET}_{\mathrm{B}}-\mathrm{R}$ with $\mathrm{BQ}$ 788. Micromolar concentrations of $\mathrm{BQ} 123$ displaced $30 \%$ of $\left[{ }^{125} \mathrm{I}\right] \mathrm{ET}-1$ (Fig. $3 \mathrm{~A}$ ), while the remaining $70 \%$ were resistant. Concomitant treatment with BQ $123(1 \mu \mathrm{mol} / \mathrm{l})+\mathrm{BQ} 788(10 \mathrm{pmol} / \mathrm{l}$ to $1 \mu \mathrm{mol} / \mathrm{l})$ completely inhibited the BQ 123-resistant component of $\left[{ }^{125}\right.$ I]ET-1 binding. Similar results were obtained when the converse experiment was performed, e.g. total displacement of bound $\left[{ }^{125} \mathrm{I}\right] \mathrm{ET}-1$ by BQ 788 only in the presence of BQ 123 (Fig. 3B). These results indicate that $\mathrm{ET}_{\mathrm{B}}-\mathrm{R}$ accounts for $72 \%$ of the total binding sites on early gestation microvilli, while $28 \%$ are of the $\mathrm{ET}_{\mathrm{A}}-\mathrm{R}$ subtype.

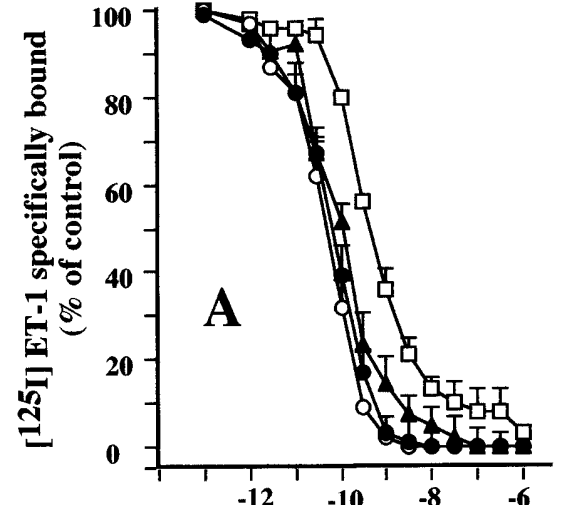

Log [agonist] (mol/L)

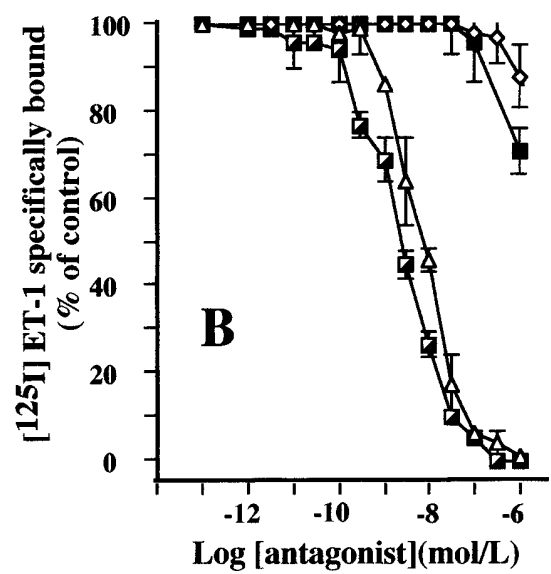

Figure 4 Displacement of $\left[{ }^{125} \mathrm{l}\right] \mathrm{ET}-1$ from term microvilli by (A)

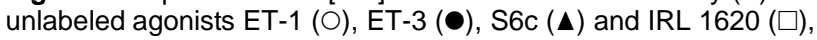
and (B) by unlabeled antagonists BQ $788(\triangle)$, IRL 2500 (half-filled squares), IRL $1038(\square)$ and $B Q 123(\diamond)$. Membranes were incubated with $\left[{ }^{125} \mathrm{I}\right] \mathrm{ET}-1$ (30 pmol/l) and increasing concentrations of unlabeled ligands. Results are expressed as percentages of control (specific binding in the absence of unlabeled ligand). Nonspecific binding, determined in the presence of $1 \mu \mathrm{mol} / \mathrm{LET}-1$, was subtracted from the total binding. Each point is the mean \pm s.E.M. of three to six experiments from different placentas performed in duplicate.

In term microvilli, $\left[{ }^{125} \mathrm{I}\right]$ ET-1 binding was inhibited by ET-1, ET-3, and the $\mathrm{ET}_{\mathrm{B}}-\mathrm{R}$ agonists $\mathrm{S} 6 \mathrm{c}$ and IRL 1620 in a monophasic manner (Hill coefficient close to unity), with $K_{\mathrm{i}}$ values of $30 \pm 4, \quad 37 \pm 6,48 \pm 8$ and $85 \pm 7 \mathrm{pmol} / \mathrm{l}$ respectively (Fig. 4A). ET-1, ET-3 and S6c had superimposable competition curves, demonstrating that the main ET-R subtype in term microvillous membranes was $\mathrm{ET}_{\mathrm{B}}-\mathrm{R}$. We confirmed this by competition binding experiments using subtype-selective antagonists (Fig. 4B). BQ 788 and IRL 2500, two selective $\mathrm{ET}_{\mathrm{B}}-\mathrm{R}$ antagonists, displaced all the $\left[{ }^{125} \mathrm{I}\right] \mathrm{ET}-1$ in a monophasic fashion with $K_{\mathrm{i}}$ values of $4.1 \pm 0.7$ and $1.6 \pm 0.1 \mathrm{nmol} / \mathrm{l}$. In contrast, the selective $\mathrm{ET}_{\mathrm{B}}-\mathrm{R}$ 
antagonist IRL 1038 reduced binding by only $24 \pm 9 \%$. Consequently, the $\mathrm{ET}_{\mathrm{B} 2}-\mathrm{R}$ subtype which was IRL 1038insensitive seemed to be mainly of the $\mathrm{ET}_{\mathrm{B}}-\mathrm{R}$ subtype in term gestation microvilli. The specific $\mathrm{ET}_{\mathrm{A}}-\mathrm{R}$ antagonist BQ 123 had very little effect at concentrations up to $1 \mu \mathrm{mol} / \mathrm{l}$.

We examined the possibility that $\mathrm{G}$ protein coupling may modulate the binding of $\left[{ }^{125}\right.$ I]ET- 1 to the two microvillous membrane preparations in binding experiments with and without guanine nucleotides. Incubation of the ligand with $1 \mathrm{mmol} / \mathrm{l} \mathrm{GTP}_{\gamma} \mathrm{S}$ had no apparent effect on [ $\left.{ }^{125} \mathrm{I}\right] \mathrm{ET}-1$ binding to either early gestation or term microvilli (data not shown).

\section{Discussion}

The present study demonstrates that specific and high affinity binding sites for [ $\left.{ }^{125} \mathrm{I}\right] \mathrm{ET}-1$ are expressed on microvillous membranes isolated from early gestation and term human placentas. Scatchard analysis of $\left[{ }^{125}\right.$ I]ET-1 binding indicated that binding affinities for early gestation and term membrane preparations are not significantly different, and that the concentration of ET-Rs on early microvilli is five times greater than that on term microvilli.

In early gestation placenta, competitive experiments demonstrated the presence of a majority of $\mathrm{ET}_{\mathrm{B}}-\mathrm{R}(72 \%$ of total receptors), with a predominance of the $\mathrm{ET}_{\mathrm{B} 2}-\mathrm{R}$ subtype. $\mathrm{ET}_{\mathrm{A}}-\mathrm{R}$ represented $28 \%$ of total receptors. In term placenta, we observed that only $\mathrm{ET}_{\mathrm{B}} \mathrm{R}$, with a majority being of the $\mathrm{ET}_{\mathrm{B} 2}-\mathrm{R}$ subtype, is present on microvillous membranes.

All seven transmembrane cell surface receptors were coupled to $\mathrm{G}$ proteins, and guanine nucleotides generally inhibited agonist binding. But we found that a non-hydrolyzable GTP analog $(\mathrm{GTP} \gamma \mathrm{S})$ has no effect on the binding of $\left[{ }^{125}\right.$ I]ET-1 to placental microvillous membranes. This is in accordance with studies demonstrating that GTP $\gamma \mathrm{S}$ does not inhibit $\left[{ }^{125} \mathrm{I}\right] \mathrm{ET}-1$ binding to crude membrane fractions of human placenta $(10$, 11 ). In contrast to other $G$ protein coupled receptors, the binding affinity of ET-Rs is not necessarily reduced by guanine nucleotides.

The human placenta has a non-uniform population of ET binding sites, with regional differences in the relative proportions of $\mathrm{ET}_{\mathrm{A}}-\mathrm{R}$ and $\mathrm{ET}_{\mathrm{B}}-\mathrm{R}$ subtypes. In term placentas, $\mathrm{ET}_{\mathrm{A}}-\mathrm{R}$ predominates in the proximal regions of vessels in the chorionic plate and stem villi, whereas $\mathrm{ET}_{\mathrm{B}}-\mathrm{R}$ is concentrated on intermediate and terminal villi and on the decidua $(14,29)$. The syncytiotrophoblast, which lines the intervillous space containing maternal blood, can be compared with a fetal endothelial layer. As for other endothelial cells which express only $\mathrm{ET}_{\mathrm{B}}-\mathrm{R}$, the term microvillous membrane also bears only $\mathrm{ET}_{\mathrm{B}}-\mathrm{R}$. Both the placenta and the trophoblast contain mainly the $\mathrm{ET}_{\mathrm{B}}-\mathrm{R}$ subtype during the first trimester (30). $\mathrm{ET}_{\mathrm{B}}-\mathrm{R}$ subtype is also present at higher density on extravillous trophoblast, suggesting that $\mathrm{ET}_{\mathrm{B}}-\mathrm{R}$ is involved in regulating the invasion of the extravillous trophoblast (31).

We found that there are five times more ET-Rs on early gestation microvillous placental membranes than on membranes from term placentas. This is compatible with the results obtained in whole placental membranes showing a decrease in the ET-R concentration from the first to the third trimester of pregnancy $(13,14)$. The term placenta appears to be an important source of ETs. The preproET-1 and ET-3 genes are expressed in the placental villi $(32,33)$, in syncytiotrophoblasts in culture (34), and, for the preproET-1, in cytotrophoblasts (35). The preterm placenta expressed little preproET-1, but the term placenta had significantly more, suggesting that the concentration of preproET-1 mRNA in human placenta changes during development (36). IrETs have been detected in the syncytiotrophoblast layer of term human placental villi and in the endothelium of feto-placental vessels, in the extravillous cytotrophoblast of the basal and chorionic plates and in trophoblasts in culture (37-39). ET-1 secreted by trophoblasts could reach other nearby placental structures. Because the trophoblast and fetal vessels lie close together, ET-1 may influence regulation of the fetoplacental circulation. ETs could also directly enter the maternal intervillous blood space and contribute, along with the ET produced by decidual cells (40), to the large amount of ir ETs found at term in this circulation, which is specific to the human feto-maternal interface (16). Consequently, these circulating ETs could act in a paracrine way to regulate myometrial contractility, especially at parturition. The high affinity ET-1 binding sites on the microvillous membrane may indicate an autocrine feedback pathway, whereby ET-1 regulates its own synthesis or release and may help specific trophoblast functions. ET-1 and ET-3 both increase the release of progesterone by syncytiotrophoblasts in culture (41), suggesting an autocrine role of ETs in the control of placental steroidogenesis. The fact that ET- 3 is more effective than ET-1 in stimulating progesterone production is in agreement with the presence of predominantly $\mathrm{ET}_{\mathrm{B}}-\mathrm{R}$ subtypes on the microvillous membrane. The mitogenic properties of ETs might also indicate that these peptides are involved in placental growth, as ET-1 stimulates mitogenesis in first-trimester human placental fibroblasts (36) and the proliferation and invasion of first-trimester cytotrophoblastic cells in vitro (42). The in vitro ET-1 effect on proliferation is mediated by both $\mathrm{ET}_{\mathrm{A}}-\mathrm{R}$ and $\mathrm{ET}_{\mathrm{B}} \mathrm{R}$ subtypes, while the effect of ET-1 on the invasion of trophoblastic cells is mediated by the $\mathrm{ET}_{\mathrm{B}}-\mathrm{R}$ subtype only (43). We found that the number of $\mathrm{ET}_{\mathrm{A}}-\mathrm{R}$ on early gestation microvillous membrane accounts for $28 \%$ of total receptors. The physiological function of these $\mathrm{ET}_{\mathrm{A}}-\mathrm{R}$ in placental development remains to be clarified.

The fate of the ETs released from the placenta at the feto-maternal interface is not well understood. Functional $\mathrm{ET}_{\mathrm{B}}$-Rs are clearance receptors in the rat lung and 
human astrocytoma U373 MG cells $(44,45)$. The presence of mainly $\mathrm{ET}_{\mathrm{B}} \mathrm{-R}$ on the placental microvillous membrane suggested that this membrane may be an important site of ET clearance. $\mathrm{ET}_{\mathrm{B}}-\mathrm{R}$ could play a major protective role by modulating the concentration of ETs in the maternal intervillous blood space. These receptors could thus be important in disorders of gestation such as pre-eclampsia and premature labor. The etiology of pre-eclampsia is unknown, but the placenta appears to play a major role, since the trophoblasts do not invade the maternal uterine tissues correctly, leading to placental ischemia and altered endothelial cell function, which in turn increases ET production $(42,46,47)$. Thus, altered $\mathrm{ET}_{\mathrm{B}}-\mathrm{R}$ production and/or function in the placental microvillous membrane may contribute to pathogenesis by reducing ET clearance, leading to higher concentrations of circulating ET at the feto-maternal interface.

\section{Acknowledgements}

We are grateful to Dr M Breuiller-Fouché and Dr G Germain for useful discussions and critical reading of the manuscript and to Ms M Verger for her excellent secretarial aid.

\section{References}

1 Inoue A, Yanagisawa M, Kimura S, Kasuya Y, Miyauchi T, Goto K et al. The human endothelin family: three structurally and pharmacologically distinct isopeptides predicted by three separate genes. Proceedings of the National Academy of Sciences of the USA $1989862863-2867$.

2 Hocher B, Thöne-Reineke C, Bauer C, Raschack M \& Neumayer $\mathrm{HH}$. The paracrine endothelin system: pathophysiology and implications in clinical medicine. European Journal of Clinical Chemistry and Clinical Biochemistry 199735 175-189.

3 Arai H, Hori S, Aramori I, Ohkubo H \& Nakanishi S. Cloning and expression of a cDNA encoding an endothelin receptor. Nature $1990348730-732$.

4 Sakurai T, Yanagisawa M, Takuwa Y, Miyazaki H, Kimura S, Goto $\mathrm{K}$ et al. Cloning of a cDNA encoding a non-isopeptideselective subtype of the endothelin receptor. Nature 1990348 $732-735$.

5 Karne S, Jayawickreme CK \& Lerner MR. Cloning and characterization of an endothelin-3 specific receptor (ETc receptor) from Xenopus laevis dermal melanophores. Journal of Biological Chemistry 1993268 19126-19133.

6 Wang Y, Rose PM, Webb ML \& Dunn MJ. Endothelins stimulate mitogen-activated protein kinase cascade through either $\mathrm{ET}_{\mathrm{A}}$ or $\mathrm{ET}_{\mathrm{B}}$. American Journal of Physiology $1994267 \mathrm{C} 1130-\mathrm{C} 1135$.

7 Smith PL, Lee CP, Pullen M, Ohlstein EH, Beck G, Eddy EP et al. Non peptide endothelin receptor antagonists. IV. Identification of receptors in rabbit colonic muscosa and smooth muscle and correlation with physiological effects. Journal of Pharmacology and Experimental Therapeutics 1995272 1204-1210.

8 Masaki T. Possible role of endothelin in endothelial regulation of vascular tone. Annual Review of Pharmacology and Toxicology 1995 $35235-255$

9 Fischli W, Clozel M \& Guilly C. Specific receptors for endothelin on membranes from human placenta. Characterization and use in a binding assay. Life Sciences 198944 1429-1436.
10 Wilkes BM, Mento PF, Hollander AM, Maita ME, Sung S \& Girardi EP. Endothelin receptors in human placenta: relationship to vascular resistance and thromboxane release. American Journal of Physiology 1990258 E864-E870.

11 Kilpatrick SJ, Roberts JM, Lykins DL \& Taylor RN. Characterization and ontogeny of endothelin receptors in human placenta. American Journal of Physiology 1993264 E367-E372.

12 Cervar M, Kainer F \& Desoye G. Pre-eclampsia and gestational age differently alter binding of endothelin-1 to placental and trophoblast membrane preparations. Molecular and Cellular Endocrinology $199511065-71$.

13 Robaut C, Mondon, F, Bandet J, Ferré F \& Cavero I. Regional distribution and pharmacological characterization of $\left[{ }^{125} \mathrm{I}\right] \mathrm{endo}-$ thelin-1 binding sites in human fetal placental vessels. Placenta $19911255-67$.

14 Rutherford RAD, Wharton J, McCarthy A, Gordon L, Sullivan MHF, Elder MG et al. Differential localization of endothelin $\mathrm{ET}_{\mathrm{A}}$ and $\mathrm{ET}_{\mathrm{B}}$ binding sites in human placenta. British Journal of Pharmacology 1993109 544-552.

15 Mondon F, Malassiné A, Robaut C, Vial M, Bandet J, Tanguy G et al. Biochemical characterization and autoradiographic localization of $\left[{ }^{125}\right] \mathrm{I}$ endothelin-1 binding sites on trophoblast and blood vessels of human placenta. Journal of Clinical Endocrinology and Metabolism 199376 237-244.

16 Bourgeois C, Mignot TM, Carbonne B \& Ferré F. Endothelins and human placental growth. Trophoblast Research 199710 259-277.

17 Williams DL, Jones KL, Pettibone DJ, List EV \& Clineschmidt BV. Sarafotoxin S6c: an antagonist which distinguishes between endothelin receptor subtypes. Biochemical and Biophysical Research Communications 1991175 556-561.

18 Takai M, Umemura I, Yamasaki K, Watakabe T, Fujitani Y, Oda et al. A potent and specific agonist, Suc- $\left[\mathrm{Glu}^{9}, \mathrm{Ala}^{11,35}\right]$ endothelin$1(8-21)$, IRL 1620, for the $\mathrm{ET}_{\mathrm{B}}$ receptor. Biochemical and Biophysical Research Communications 1992184 953-959.

19 Ishikawa K, Ihara M, Noguchi K, Mase T, Mino N, Saeki T et al. Biochemical and pharmacological profile of a potent and selective endothelin B-receptor antagonist, BQ-788. Proceedings of the National Academy of Sciences of the USA $1994914892-4896$.

20 Früh Th, Saika H, Svensson L, Pitterna Th, Sakaki J, Okada T et al. IRL 2500 : a potent $\mathrm{ET}_{\mathrm{B}}$ selective endothelin antagonist. Bioorganic and Medicinal Chemistry Letters $199662323-2328$.

21 Urade Y, Fujitani Y, Oda K, Watakabe T, Umerura I, Takai M et al. An endothelin B receptor-selective antagonist: IRL 1038 [CyCys]endothelin [11- 21]. FEBS Letters 1992311 12-16.

22 Ihara M, Noguchi K, Sacki T, Fukuroda T, Tsuchida S, Kimura S et al. Biological profiles of highly potent novel endothelin antagonists selective for the $\mathrm{ET}_{\mathrm{A}}$ receptor. Life Sciences 198950 247-255.

23 Smith NC, Bruch MG \& Luckett S. Preparation of human placental villous surface membrane. Nature 1974252 302-303.

24 Alsat E, Bouali Y, Goldstein S, Malassiné A, Laudat MH \& Cedard L. Characterization of specific low-density lipoprotein binding sites in human term placental microvillous membranes. Molecular and Cellular Endocrinology 198228 439-453.

25 Alsat E, Bouali Y, Goldstein S, Malassiné A, Berthelier M, Mondon $\mathrm{F}$ et al. Low-density lipoprotein binding sites in the microvillous membranes of human placenta at different stages of gestation. Molecular and Cellular Endocrinology 198438 197-203.

26 Cheng Y \& Prusoff WH. Relationship between the inhibition constant $\left(K_{\mathrm{i}}\right)$ and the concentration of inhibitor which causes 50 percent inhibition $\left(\mathrm{IC}_{50}\right)$ of an enzymatic reaction. Biochemical Pharmacology 197322 3099-3108.

27 Munson PJ \& Rodbard D. LIGAND: a versatile computerized approach for characterization of ligand-binding systems. Annals of Clinical Biochemistry 1980107 220-239.

28 Sudjarwo SA, Hori M, Tanaka M, Matsuda T, Okada T \& Karaki H. Subtypes of endothelin $\mathrm{ET}_{\mathrm{A}}$ and $\mathrm{ET}_{\mathrm{B}}$ receptors mediating venous smooth muscle contraction. Biochemical and Biophysical Research Communications $1994200627-633$. 
29 Kohnen G, Mackenzie F, Collett GP, Campbell S, Davenport AP Cameron IT et al. Differential distribution of endothelin receptor subtypes in placentae from normal and growth-restricted pregnancies. Placenta 199718 173-180.

30 Cervar M, Weiss U, Barth S, Hah T, Kainer F \& Desoye G. Differential expression of endothelin receptor subtypes in first trimester and term trophoblast and human placental tissue. Placenta 199718 A16.

31 Kohnen G, Thomson AJ, Lindop G, Norman JE \& Cameron IT. Expression of endothelin receptors in first trimester human placenta. Placenta 199718 A34.

32 Benigni A, Gaspari F, Orisio S, Bellizzi L, Amuso G, Frusca T et al. Human placenta expresses endothelin gene and corresponding protein is excreted in urine in increasing amounts during normal pregnancy. American Journal of Obstetrics and Gynecology 1991 $164844-848$.

33 McMahon LP, Redman CWG \& Firth JD. Expression of the three endothelin genes and plasma levels of endothelin in pre-eclamptic and normal gestations. Clinical Science 199385 417-424.

34 Robert B, Malassiné A, Bourgeois C, Mignot TM, Cronier L, Ferrré $\mathrm{F}$ et al. Expression of endothelin precursor genes in human trophoblast in culture. European Journal of Endocrinology 1996 134 490-496.

35 Fant ME \& Nanu L. Human placental endothelin: expression of endothelin-1 mRNA by human placental fibroblasts in culture. Molecular and Cellular Endocrinology 1995109 119-123.

36 Fant ME, Nanu L \& Word RA. A potential role for endothelin-1 in human placental growth: interactions with the insulin-like growth factor family of peptides. Journal of Clinical Endocrinology and Metabolism 199274 1158-1163.

37 Hemsén A, Gillis C, Larsson O, Haegerstrand A \& Lundberg JM. Characterization, localization and actions of endothelins in umbilical vessels and placenta of man. Acta Physiologica Scandinavica 1991143 395-404.

38 Van Papendorp CL, Cameron IT, Davenport AP, King A, Barker PJ, Huskisson NS et al. Localization and endogenous concentrations of endothelin-like immunoreactivity in human placenta. Journa of Endocrinology 1991131 507-511.
39 Malassiné A, Cronier L, Mondon F, Mignot TM \& Ferré F. Localization and production of immunoreactive endothelin-1 in the trophoblast of human placenta. Cell and Tissue Research 1993 271 491-497.

40 Kubota T, Kamata S, Hirata Y, Eguchi S, Imami T, Marumo F et al. Synthesis and release of endothelin-1 by human decidual cells. Journal of Clinical Endocrinology and Metabolism 199275 12301241.

41 Mignot TM, Malassiné A, Cronier L \& Ferré F. Endothelin increases progesterone release by human trophoblast in culture. In Endothelin in Endocrinology: New Advances, vol. 15, pp 277283. Eds Baldi E, Maggi M, Cameron IT \& Dunn MJ. Ares-Serono Symposia Publications, 1995.

42 Cervar M, Puerstner P, Kainer F \& Desoye G. Endothelin-1 stimulates the proliferation and invasion of first trimester trophoblastic cells in vitro. A possible role in the etiology of preeclampsia? Journal of Investigative Medicine 199644 447-453.

43 Cervar M, Kainer F \& Desoye G. Endothelin-1 stimulates the invasion of first trimester trophoblast specifically via the B-type receptor, whereas its action on proliferation is mediated by both receptor subtypes. Placenta 199718 A15.

44 Fukuroda T, Fujikawa T, Ozaki S, Ishikawa K, Yano M \& Nishikibe $\mathrm{M}$. Clearance of circulating endothelin-1 by $\mathrm{ET}_{\mathrm{B}}$ receptors in rats. Biochemical and Biophysical Research Communications 1994199 1461-1465.

45 Wu-Wong JRT, Chiou WJ, Magnuson SR \& Opgenorth TJ. Endothelin receptor in human astrocytoma U373MG cells: binding, dissociation, receptor internalization. Journal of Pharmacology and Experimental Therapeutics 1995 274 499-507.

46 Roberts JM \& Redman CWG. Pre-eclampsia: more than pregnancy-induced hypertension. Lancet 1993341 1447-1451.

47 Walker JJ. Hypertension in pregnancy. British Journal of Obstetrics and Gynaecology 1994101 639-644.

Received 15 December 1997

Accepted 27 April 1998 